\title{
The impact of anthropogenic food supply on fruit consumption by dusky-legged guan (Penelope obscura Temminck, 1815): potential effects on seed dispersal in an Atlantic forest area
}

\author{
J. Vasconcellos-Neto ${ }^{a}$, R. R. Ramos ${ }^{a *}$ and L. P. Pinto ${ }^{a}$ \\ ${ }^{a}$ Departamento de Biologia Animal, Instituto de Biologia, Universidade Estadual de Campinas - Unicamp, \\ Rua Monteiro Lobato, 255, CP 6109, CEP 13083-862, Campinas, SP, Brazil \\ *e-mail: rognerramos@gmail.com
}

Received: April 10, 2014 - Accepted: July 7, 2014 - Distributed: November 30, 2015

(With 3 figures)

\begin{abstract}
Frugivorous birds are important seed dispersers and influence the recruitment of many plant species in the rainforest. The efficiency of this dispersal generally depends on environment quality, bird species, richness and diversity of resources, and low levels of anthropogenic disturbance. In this study, we compared the sighting number of dusky-legged guans (Penelope obscura) by km and their movement in two areas of Serra do Japi, one around the administrative base (Base) where birds received anthropogenic food and a pristine area (DAE) with no anthropogenic resource. We also compared the richness of native seeds in feces of birds living in these two areas. Although the abundance of $P$. obscura was higher in the Base, these individuals moved less, dispersed $80 \%$ fewer species of plants and consumed $30 \%$ fewer seeds than individuals from DAE. The rarefaction indicated a low richness in the frugivorous diet of birds from the Base when compared to the populations from DAE. We conclude that human food supply can interfere in the behavior of these birds and in the richness of native seeds dispersed.
\end{abstract}

Keywords: behavior, conservation, frugivory, ecological impacts, Serra do Japi.

\section{O impacto do fornecimento de alimentos humanos no consumo de frutos por jacuguaçus (Penelope obscura Temminck, 1815): potenciais efeitos na dispersão de sementes em uma área de Mata-Atlântica}

\begin{abstract}
Resumo
Aves frugívoras são importantes dispersoras de sementes e influenciam no recrutamento de muitas espécies na floresta tropical. A eficiência dessa dispersão geralmente depende da qualidade do meio ambiente, das espécies de aves envolvidas, da riqueza e diversidade de recursos e de baixos níveis de impactos antrópicos. Neste estudo nós comparamos o número de avistamentos de jacuguaçus (Penelope obscura) por Km e seus movimentos em duas áreas na Serra do Japí, uma no entorno da base administrativa (Base) onde as aves receberam alimentos antropogênicos e outra em área pristina (DAE) sem fornecimento de alimentos humanos. Também comparamos a riqueza de sementes nativas nas fezes das aves que vivem nestas duas áreas. Embora a abundância de $P$. obscura tenha sido maior na Base, esses indivíduos deslocaram-se menos, dispersaram $80 \%$ menos espécies de plantas e consumiram $30 \%$ menos sementes do que os indivíduos do DAE. A rarefação indicou uma baixa riqueza na dieta frugívora das aves da Base quando comparada às populações do DAE. Concluímos que o fornecimento de alimentos humanos pode interferir no comportamento dessas aves e na riqueza de espécies de sementes nativas dispersadas.
\end{abstract}

Palavras-chave: comportamento, conservação, frugivoria, impactos ecológicos, Serra do Japi.

\section{Introduction}

Seed dispersal is a fundamental mechanism for the maintenance of plant diversity in tropical forests, where most trees and shrubs are dispersed by animals (Howe and Estabrook, 1977; McKey, 1975). Frugivorous birds are important dispersers of a large number of plants, and their densities and behavior influence the recruitment of many plant species (Fadini and Marco Junior, 2004; Mikich,
2002; Morellato and Leitão Filho, 1992) and regeneration processes (Galetti et al., 2013; Mello et al., 2008).

Thus, the extinction or decline in populations of frugivores may have strong impacts on forest vegetation, altering the abundance, dominance, and diversity of plants (Silva and Tabarelli, 2000), and causing a decline in gene flow via seed (Godoy and Jordano, 2001). On the other hand, human 
actions are the greatest causes of habitat fragmentation, forest degradation and biodiversity loss (Harper et al., 2005). Areas with a high degree of anthropogenic disturbance have lower richness and frequencies of visitations of frugivorous birds than preserved sites (Staggemeier and Galetti, 2007).

Among Neotropical seed dispersal birds, the family Cracidae is of special interest as it comprises large individuals $(42-95 \mathrm{~cm})$; with 51 described species, of which 22 occur in Brazil (BirdLife, 2014). Due to their large size, cracids are relatively easy to observe, and are known to contribute to forest regeneration by dispersing and/or predating seeds (Brooks, 2006). Approximately $31.5 \%$ of ornithocoric fruits of Neotropical trees are larger than $15 \mathrm{~mm}$, and they depend on large birds, such as cracids, for the dispersal of their seeds (Santamaría and Franco, 2000; Silva and Tabarelli, 2000). These frugivores are important for conservation programs in the Neotropics (García-Moreno et al., 2007), as they are ecological indicators (susceptible to habitat destruction) (Brooks, 2006) and are also responsible for most of the vertebrate biomass in Neotropical forests, serving as a food source for carnivores (Eisenberg, 1980) and native people (Barros et al., 2011; Peres, 2000).

In Serra do Japi, the cracid Penelope obscura Temminck, 1815 (dusky-legged guan) is a frugivorous bird that has already been affected by the loss and modification of its habitat (Silva, 1992). These guans are considered excellent dispersers and play a key role in regenerative processes of forest fragments (Zaca et al., 2006). This species has a wide gape, enabling the ingestion of a wide size range of diaspores (Fadini and Marco Junior, 2004; Pizo, 2004). Their flexible feeding behavior and digestive tracts are adapted to a generalist diet (Muñoz and Kattan, 2007), composed of shoots, leaves, flower buds, and invertebrates, but mostly (70-83\%) by fruits (Ottoni et al., 2009). Unlike curassows (Cracinae), chachalacas and guans (Penelopinae) are not primarily seed predators because they don't have gizzard and therefore do not grind seeds (Guix, 2006; Guix and Ruiz, 1997); are typical frugivorous, with the ability to disperse large quantities of seeds (Brooks, 2006; Muñoz and Kattan, 2007; Santamaría and Franco, 2000). Due to their extensive home range similar to those of other large birds (Mace et al., 1983; Parra et al., 2001; Yumoto, 1999), dusky-legged guans are able to disperse seeds over long distances.

Near urban areas, however, observations throughout the year have shown that $18.6 \%$ of the diet of populations of $P$. superciliaris Temminck, 1815 was composed of anthropogenic food. A decrease in food search, reducing its movement and, significantly changing seed dispersal to adjacent areas may occur (Ottoni et al., 2009). Currently, although there are no major concerns regarding environmental degradation or fragmentation in Serra do Japi, in some areas, residents offer foods such as corn and leftovers (rice, beans, lettuce, and tomato) to groups of P. obscura.

The central question of this study was to investigate how the food supply introduced by humans may change the behavior and the diet of $P$. obscura and how these changes affect the diversity of seeds dispersed in the Atlantic forest. Our hypothesis predicts that with additional supply of anthropogenic food, the sighting number of guans by $\mathrm{km}$ and resting time of this bird is be greater when compared to another area of the forest where this intervention does not occur. Therefore, we expect this cracid to move more to obtain food in pristine areas, resulting in greater mobility, lower abundance, and consequently a higher species richness of seeds in its droppings.

\section{Material and Methods}

\subsection{Study area}

We worked in a continuous area of the Atlantic forest in Serra do Japi, Jundiai, São Paulo State, Brazil, during the summer (March of 2007 and February of 2011). The predominant vegetation is Semi-deciduous Mesophytic Forest with canopy height ranging from 10 to $15 \mathrm{~m}$ and dense understory (Leitão Filho, 1992). The altitude of the region ranges from 700 to $1300 \mathrm{~m}$, with rainfall around $1900 \mathrm{~mm}$ for the South side and $1367 \mathrm{~mm}$ for the Northwest side (Serra do Japi, 2015). The climate is Cwb (Köppen classification) (Peel et al., 2007), altitudinal tropical with cold and dry winters (May to October) and mild humid summers (November to April); and average temperatures ranging from 11.8 to $22.2^{\circ} \mathrm{C}$ (Pinto, 1992).

We selected two sites, one in the surroundings of the Center for Environmental Educational and Ecological Studies, known as the Base (23 13' 53' s, 46 56' $12^{\prime}$ ' w), where food leftovers are offered at least in three points; and the second one, located $3.5 \mathrm{~km}$ away at the Base, a pristine area (with no human interference), known as DAE (2313'40' s, 46 58'60' w).

\subsection{Study species}

The dusky-legged guan (Penelope obscura bronzina Hellmayr 1914) (Cracidae: Penelopinae) is a frugivorous and seed disperser; measuring $73 \mathrm{~cm}$ and weighing $1200 \mathrm{~g}$ approximately. It occurs in mountains up to $2200 \mathrm{~m}$, hills and coastal plains of southern and southeastern Brazil, in several habitats such as primary and secondary Atlantic forest, high-altitude forests, riparian habitats, lake margins and forest fragments (Frisch and Frisch, 2005; Sick, 1997).

\subsection{Data collection}

We walked at an average speed of $3 \mathrm{~km} / \mathrm{h}$ in silence along trails in the two forest areas and we estimated the frequency of $P$. obscura based on the sighting number registered per kilometer of track (Lopes and Ferrari, 2000). During the 5 days of observations and sampling, we traveled $13.86 \mathrm{~km}$ in the area surrounding the Base and $38.24 \mathrm{~km}$ in the DAE area, over five different tracks in each site. Our observations were standardized and conducted approximately 30 meters away from individuals to avoid behavioral changes. Although the observations and counts have been made in different days and distant points along the tracks, the guans were not tagged, so we are not sure if all records were from different birds. 
We measured the mobility of individuals of the DAE and the Base through observations and "sighting time" in seconds (s) (time when guans remained under our vision), which consisted of the sums of resting and movement times. Thus, we classified their behaviors as: (a) position - perched or walking on the ground, and (b) activity in the canopy - resting on a perch or moving. When an individual rested on a perch for more than 300 seconds we stopped the observation and considered it inactive. We observed dusky-legged guans from 5:30 to 11:30 AM, when animals are most active (Zaca et al., 2006). Sighting time was measured only for birds observed in the canopy.

In all, we recorded 79 behavioral observations and 86 sightings of Dusky-lagged guans along the tracks (sighting number per linear $\mathrm{Km}$ ) at the Base; in the DAE area there were 26 behavioral observations and 26 registers of guans along the tracks (sighting number per linear $\mathrm{Km}$ ).

In order to compare the richness of native seeds in feces of dusky-legged guans, we collected 20 fecal samples (intact and recent) in each area, in the morning, to avoid problems with secondary dispersal.

In the laboratory, we washed fecal samples and separated seeds, which were counted and identified at species or generic levels. To identify the plant species used as food by $P$. obscura, we used Lorenzi (2008) and compared the seeds found in fecal samples with seeds of plants fruiting at the period of our study at both study sites in Serra do Japi. We also verify if the plants producing fruit occurred in one or both study sites.
We recorded the presence of crop seeds offered to dusky-legged guans by residents, but these items were not considered in the comparisons of diversity and dominance of native plant species.

\subsection{Data analyses}

To test differences in behavioral frequencies found in the two regions, we used $G$-tests-Yates in contingency tables with significance levels set at $\alpha=0.05$; to this analysis we use the BioEstat 5.0 free software (Ayres et al., 2007).

In order to compare the data of study areas, including the frequency of $P$. obscura per km of track and the sighting time in seconds, we applied the "W" Tests, indicated to unequal variances (Ruxton, 2006); with significance levels set at $\alpha$ $=0.05$, standard error (SE) and $95 \%$ confidence interval (95\% CI); we use R 3.02 free software (R Development Core Team, 2008).

In order to compare the richness of seed species in fecal samples of DAE and Base, we use individual rarefaction with $95 \% \mathrm{CI}$, the most indicated method to compare species richness in samples with different sizes (Adrain et al., 2000); to this analysis we use the PAST version 3.0 free software (Hammer et al., 2001).

\section{Results}

We observed dusky-legged guans moving through the canopy and roosting on thin branches to feed on fruits, or walking on the ground of the forest where they could find fallen fruits (see Figure 1a and Table 1). When resting on
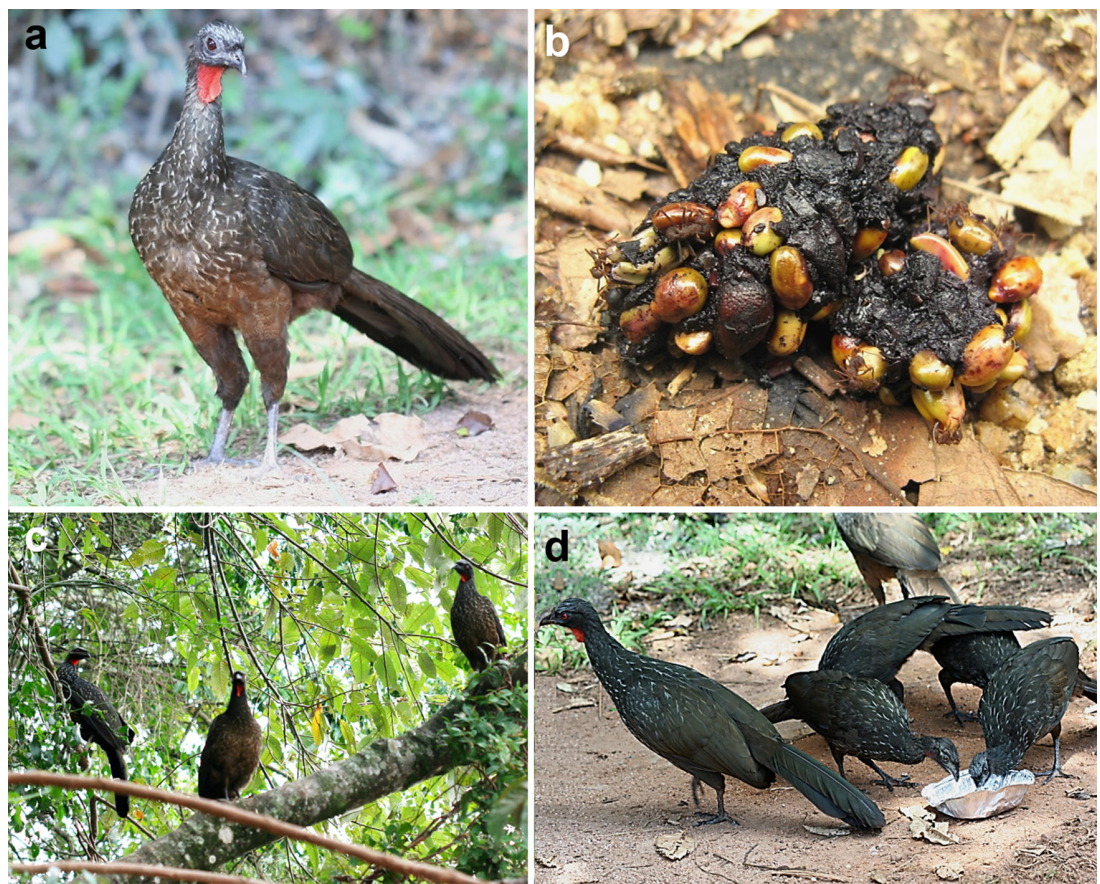

Figure 1. Overview of the behavior of dusky-legged guans in Serra do Japi: (a) Single individual walking and foraging on the ground of forest where fallen fruits can be found; (b) dusky-legged guan's feces with seeds of wild fruits (Myrtaceae) on the ground of the forest; (c) Group resting on canopy branches, near the area where food provided around the Base; (d) Group feeding on leftovers offered at the Base. 
canopy branches, feces were released from the perch or during movements on the forest ground (see Figure 1b). In the DAE, birds moved extensively searching for fruits, and $96.2 \%(n=25)$ of all displacements occurred through the canopy (see Table 1); $65.4 \%(\mathrm{n}=17)$ of individuals moved alone. In these pristine areas, we did not observe any dusky-legged guans in prolonged rest on perches, this short sighting time showed quick movements of these birds (see Table 1 and Figure 2a). On the other hand, where anthropogenic food ( $2 \mathrm{~kg}$ twice a day) was available near houses and the Base, we observed birds perched in nearby trees (see Figure 1c) waiting for leftovers to be offered. In this case we recorded $37 \%$ of occurrences $(n=19)$ of dusky-legged guans perched in prolonged rest and $63 \%(\mathrm{n}=32)$ in motion (see Table 1$)$. At the Base $35.4 \%$ $(n=28)$ of dusky-legged guans occurrences were on the ground and foraging on leftovers (see Figure 1d) while $64.6 \%(n=51)$ were on perches (see Table 1). Behavioral differences were observed between the populations of the two areas, both for positioning (perched or on the ground) $(\mathrm{P}<0.001 ; G$-test-Yates $=10.2)$ and for the activity within the canopy (moving or resting) $(\mathrm{P}<0.0002$; $G$-test-Yates $=13.8)($ see Table 1$)$.
The "sighting time (s)" was significantly longer in the area around the Base $(223.1 \mathrm{~s} \pm 12.0 \mathrm{~s}$ and $199.1 \mathrm{~s}-247.1 \mathrm{~s}$; mean $\pm \mathrm{SE}$ and $95 \% \mathrm{CI})$ than DAE area $(22.8 \mathrm{~s} \pm 1.2 \mathrm{~s}$ and 20.5-25.2 s; mean $\pm \mathrm{SE}$ and $95 \% \mathrm{CI}),(\mathrm{P}<0.0000001$; W-test $=11.7)($ see Figure 2a), and the frequency of duskylegged guans by $\mathrm{km}$ was higher in the Base area $(6.3 \pm 1.2$ and 3.2-9.6; mean $\pm \mathrm{SE}$ and $95 \% \mathrm{CI}$ ), when compared to the DAE area $(0.7 \pm 0.1$ and $0.4-0.9$; mean $\pm \mathrm{SE}$ and $95 \%$ $\mathrm{CI}),(\mathrm{P}<0.001$; W-test $=4.8)$ (see Figure 2b).

Dusky-legged guans present in the DAE fed on 10 native species of fruits, while in the Base, only two, although the same fruit plants occur in both areas (see Table 2). Although the frequency of dusky-legged guans was nine times greater in the Base than in the DAE area, the richness of seeds species per fecal sample was higher in the DAE, showing a greater use of the native resources available (Rarefaction; 95\% CI) (see Figure 3). Dusky-legged Guans of the Base dispersed $80 \%$ fewer species of plants, and quantitatively consumed $30 \%$ fewer seeds than individuals from the DAE (see Table 2).

At the Base we found a remarkable concentration of dusky-legged guans feces on the ground below perches, where the soil is compacted and regularly weeded, hindering germination and preventing the establishment of seedlings.

Table 1. Frequencies of the behaviors of P. obscura in the Base and DAE areas, showing activity in the canopy (moving or resting on perches) and their position in the forest (perched or walking on the ground).

\begin{tabular}{ccccc}
\hline Local & \multicolumn{2}{c}{ Activity in the canopy ${ }^{\text {* }}$} & \multicolumn{2}{c}{ Positioning ${ }^{\text {b* }}$} \\
\hline \multirow{2}{*}{ Base } & moving & $\mathrm{n}=32(63 \%)$ & perched & $\mathrm{n}=51(64.6 \%)$ \\
& resting & $\mathrm{n}=19(37 \%)$ & walking & $\mathrm{n}=28(35.4 \%)$ \\
& total & $\mathrm{n}=51(100 \%)$ & total & $\mathrm{n}=79(100 \%)$ \\
\hline moving & $\mathrm{n}=25(100 \%)$ & perched & $\mathrm{n}=25(96.2 \%)$ \\
& resting & $\mathrm{n}=0(0 \%)$ & walking & $\mathrm{n}=1(3.8 \%)$ \\
& total & $\mathrm{n}=25(100 \%)$ & total & $\mathrm{n}=26(100 \%)$ \\
\hline
\end{tabular}

a* $(\mathrm{P}<0.0002 ; G$-test-Yates $) .{ }^{\mathrm{b} *}(\mathrm{P}<0.001 ; G$-test-Yates $)$.
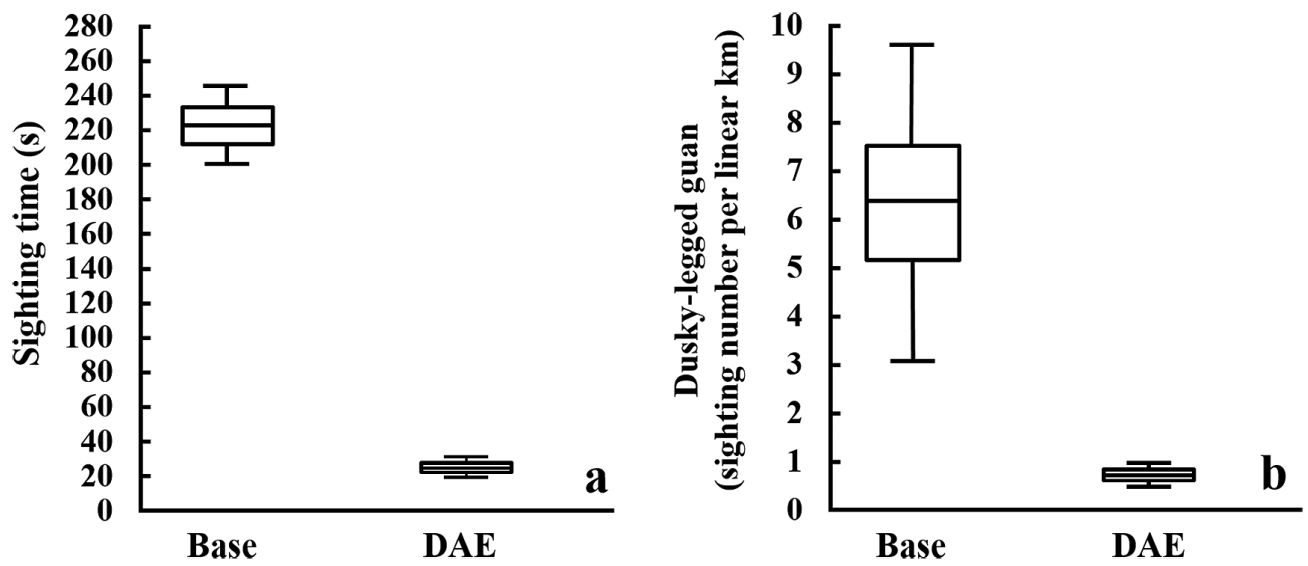

Figure 2. Comparative data between groups of $P$. obscura of the Base and DAE: (a) Sighting time in seconds $(\mathrm{P}<0.0000001$; $\mathrm{W}$-test $=11.7)$; (b) Sighting number of dusky-legged guan per kilometer walked $(\mathrm{P}<0.001$; W-test $=4.8)$; central lines and borders in each box plot indicate the mean $\pm \mathrm{SE}$, whereas whiskers indicate the $95 \%$ confidence interval range. 
Table 2. Diversity of seeds of native species found in feces of $P$. obscura around the Base ( $\mathrm{n}=20$ samples of feces) and in the forest of DAE ( $\mathrm{n}=20$ fecal samples).

\begin{tabular}{|c|c|c|c|}
\hline Area & Taxa & Number of seeds & Frequency $(\%)$ \\
\hline \multirow{3}{*}{ Base $^{\mathrm{a}}$} & Styracaceae: Styrax pohlii A. DC. & 109 & 96.5 \\
\hline & Cecropiaceae: Cecropia sp. & 4 & 3.5 \\
\hline & Total & 113 & 100 \\
\hline \multirow{16}{*}{ DAE } & Annonaceae: & & \\
\hline & Rollinia mucosa (Jacq.) Baill & 5 & 3.1 \\
\hline & $\begin{array}{l}\text { Rollinia sylvatica (A. St.-Hil.) Mart. } \\
\text { cf. Chrysobalanaceae: }\end{array}$ & 9 & 5.5 \\
\hline & sp. 1 & 82 & 50.3 \\
\hline & Euphorbiaceae: & & \\
\hline & sp. 1 & 4 & 2.5 \\
\hline & Myrtaceae: & & \\
\hline & Eugenia sp. & 9 & 5.5 \\
\hline & Myrcia sp. & 13 & 8.0 \\
\hline & Psidium cf. cattleianum Sabine & 2 & 1.2 \\
\hline & Psidium guajava $\mathrm{L}$. & 18 & 11.0 \\
\hline & Solanaceae: & & \\
\hline & Solanum pseudoquina A. St.-Hill. & 6 & 3.7 \\
\hline & Styracaceae: & & \\
\hline & Styrax pohlii & 15 & 9.2 \\
\hline & Total & 163 & 100 \\
\hline
\end{tabular}

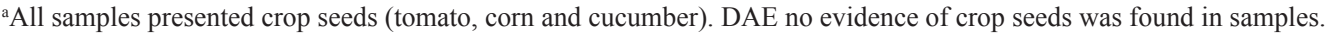

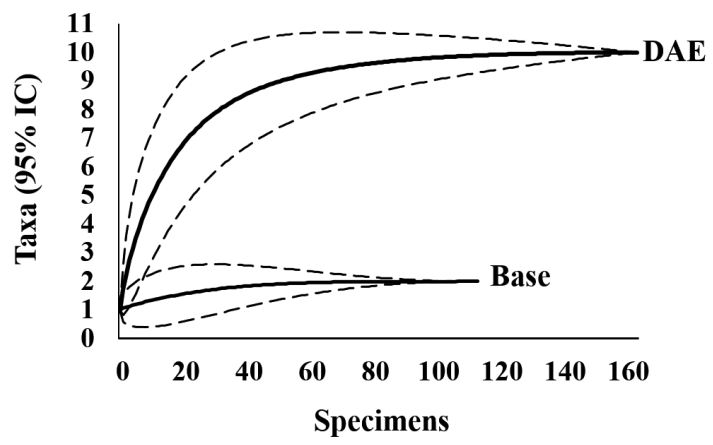

Figure 3. The diversity and richness of native seed species per fecal sample in the DAE and Base, are demonstrated by the relationship between the number of Taxa and the number of seed specimens. Bold line indicate the cumulative curves of Taxa according to Individual Rarefaction and the dashed lines showed the $95 \%$ confidence interval range.

\section{Discussion}

\subsection{The densification of guans}

According to João Vasconcellos-Neto (unpublished data), the clustering of guans around the Base started after 1992, apparently due to the supply of food by humans, and reached 76 individuals around the base at some point.

Although the comparisons included only two areas in the Serra do Japi, the structure and composition of the forest around the Base resemble those found in DAE (Leitão Filho, 1992; Morellato and Leitão Filho, 1992). At first our results suggests that the differences in richness of seeds eaten by guans of DAE and Base, are due to different availability of native resource between two forest areas. Despite the concentrations and distributions of wild fruit that can vary seasonal and spatially, we observe that large number of guans stay concentrated at the Base during most part of day and throughout the seasons, instead of searching for food in other parts of the forest. In this case if the behavior of Base guans groups were principally influenced by patterns of distributions and seasonality of fructifications, probably they would scattered as DAE guans and do not remain in the same place year after year around of administrative Base. Whatever the forest patterns in two areas, it seems that the eating behavior of guans at the Base don't depend mainly on the differences in structure or composition of the forest, but seems depend on to profitable human leftovers provided to these birds.

Personal observations by A.V.L. Freitas, in the Caparaó National Park, southeastern Brazil, indicate very similar behaviors in local populations of dusky-legged guans, which grouped around the administrative building and waited for food to be offered by park personnel. Exotic plants or crops can also serve as alternative foods for P. obscura and keep them as long-term residents in the same place (Merler et al., 2001). The guans are often seen near the sites of cultivars and there are many reports that they frequent plantations (Kattan et al., 2014); including in Brazilian coffee plantations this behavior has resulted in the production of organic coffee obtained through the coffee seeds that pass intact through the digestive tract of the guans (De Conti et al., 2013). 
Visits by frugivorous birds are positively correlated to the abundance and variety of wild resources (Saracco et al., 2005; Francisco et al., 2007) and to the low level of anthropogenic influence (Staggemeier and Galetti, 2007). On the other hand, the consumption of wild fruits can be limited by several factors such as: (a) deterrent substances (unpalatability) (Cazetta et al., 2008; Tsahar et al., 2002); (b) inadequate sizes (Wheelwright, 1985); (c) presence of hard capsules (Pascotto, 2007); (d) cryptic coloration (Schmidt et al., 2004); (e) low nutritional quality (Schaefer et al., 2003); (f) low availability (Saracco et al., 2005).

However, dusky-legged guans of Serra do Japi have been influenced by anthropogenic food supply, which changed the local abundance of the population and their foraging behavior and seed dispersal. Offering food increases the density of dispersers (Bertsch and Barreto, 2008; Parra et al., 2001), reduces the movement of birds and dispersal distance, emphasizing further aggregation patterns (Serio-Silva and Rico-Gray, 2002).

Therefore, the trade-off between handling costs and nutritional value of food could momentarily divert the birds' preference to more profitable plants in their foraging (Grant and Grant, 2006; Pascotto, 2007; Stephens et al., 2007). These factors may have contributed to dusky-legged guans feeding preferentially in areas where food was offered. It seems that these birds reduced the costs of foraging opting for easy meals, since cracids remain in same area when resources are available (Merler et al., 2001). The occurrence of cultivar seeds and low richness of native seeds in P. obscura feces of Base was an indication that these birds may be using the plentiful human food in this area. Despite this great frequency of guans used as a positive point in the environmental education programs at the administrative Base, we should use caution. We believe that the food without proper nutritional balance can bring long-term problems for these birds, as obesity (Auman et al., 2008), low mobility (Ottoni et al., 2009) and low reproductive success (Pierotti and Annett, 1991); in addition, the guans can serve as hosts between domestic and wild animals, causing more problems. However, a controlled supply of attractive resources mixed with fruit or native seeds can be applied in management programs, using the aggregation of the guans as a tool to seed dispersal. Nevertheless, to avoid the lazy behavior of guans, the food portions would be scattered and decreased gradually forcing them to disperse. To apply this type of feeding management requires a new amount of research.

\subsection{Patterns of native seed dispersal and ecological consequences}

The increase in dusky-legged guans' abundance of Base was not accompanied by an increase in the ecological role of these animals as native seed dispersers, as these individuals dispersed fewer seeds with a much lower richness.

Seeds of Myrtaceae were the most frequently found in the DAE area, in agreement with the pattern of high species richness of this family in the Atlantic forest (Rochelle et al., 2011; Tabarelli and Mantovani, 1999) and with the importance of this item to cracids (Galetti et al., 1997; Guix et al., 2001; Théry et al., 1992). In the DAE, the sighting time of dusky-legged guans was shorter since they were in constant motion looking for scattered food. The seasonal and spatial variation in fruit availability are important for seed dispersal (Fleming, 1992; Galetti, 1993; Parra et al., 2001). When resources are rare, the cracids are forced to change their diet (Merler et al., 2001; Zaca et al., 2006) and/or search for food in new areas of the forest (Kinnaird et al., 1996; Powell and Bjork, 2004).

Penelope obscura of the DAE area spent more than $90 \%$ of their time moving in the canopy. In tropical forests, frugivorous birds with this behavior are crucial to promote seed rain, scattering them through the forest. Such events are very important to the population dynamics of tropical trees with long life cycles, increasing the chances of seeds falling into gaps or suitable microhabitats for development, and decreasing the chances of predation and problems with density-dependent mortality (Muller-Landau and Hardesty, 2005). Although the ten plants consumed by P. obscura in the DAE occurred in both areas, only two species of fruit were eaten in the vicinity of the Base. Both Cecropia sp. and Styrax pohlii, typical plants of early stages of succession (Lorenzi, 2008), were found on the forest edge near the Base where dusky-legged guans were perched on nearby trees waiting for food to be offered in the feeding area. This feeding area in Base distorted the foraging and behavior patterns of $P$. obscura of Base, which accustomed to human presence, tolerated close approaches and presented prolonged resting behavior. The high number of guans in prolonged rest on the edges of forest or on the ground restricted the use of native species, reducing the likelihood of tree species seeds to be dispersed and deposited in high-quality sites for germination.

On forest edges, the climate conditions are unfavorable (Laurance et al., 2002) and further decrease the chances of establishment of seeds (Fleury and Galetti, 2004). In addition, seed dispersal near the plant origin, especially long-lived fruit trees, creates clusters with high genetic relatedness reducing the genetic diversity of local populations (Jordano et al., 2006). These saplings are subjected to adverse conditions for establishment and growth due to competition, predation (Chapman and Chapman, 1995; Howe et al., 1985; Janzen, 1970) and mechanisms of density-dependent mortality (Jordano et al., 2006). Therefore, the greatest concern for Atlantic Forest trees that produce fleshy fruits might be the dependence on zoochory to maintain their demographic and genetic structures. Besides the direct problems caused by the lack of dispersal, other organisms might be impacted due to the complex networks of ecological interactions as plant-disperser-insect interaction (Guix and Ruiz, 1997). The impoverished of vertebrate in tropical forest, lead to lower frequencies of previously manipulated fallen fruits; intact fallen fruits of many diaspore species are likely to be less attractive to a number of potentially beneficial ant species and thus reduces the chances of ant-diaspore interactions (Bieber et al., 2013). 
Therefore, changes in dispersal events seem to cause damage to the structure (Jordano et al., 2006), recruitment of plant populations (Loiselle and Blake, 2002) and the entire community in the forest (Guix, 2006; Howe, 1984). However, a big problem with functional extinction of large frugivorous is the decrease of dispersal of large viable seeds and the low fitness of plants populations originated from small seeds. This process can drive rapid evolutionary change toward the small seeds and increase the vulnerability of seedlings in Atlantic Forest (Galetti et al., 2013).

\section{Conclusion}

Even in places with low fragmentation, no hunting and low urbanization, the seemingly harmless anthropogenic food supply can promote changes in the foraging strategy of dusky-legged guans. These changes seem to have interfered in activity and the demographic patterns of this species, reducing the local consumption of native fruits and their ecological role as native seed dispersers. The food supply scenario seemed to play an analog role to the concentration of resources, and simulates a functional extinction of these cracids, which affect the seed dispersal. However, a possible sudden stop on food supply can generate consequences as increase of intraspecific competition; nevertheless, this new research will be must closely monitored and for a long time.

Therefore, the practice of providing alternative food resources should not be used because it is detrimental to the balance of the ecological process and it can reduce the richness and viability of native seeds dispersed in the Atlantic forest.

\section{Acknowledgements}

We thank the Graduate Program in Ecology of Unicamp for financial support through the discipline Topics in Field Ecology. The Research Base of Serra do Japi for lodging and authorizing research in the study area. We also thank E. Pereira for contributions, P. R. Polli for giving a beautiful picture of guan feces, G. Romero, R. B. Francini and A. V. L. Freitas for suggestions to this work, J. R. Lima and S. R. Walsh for helping and suggestions in English text.

\section{References}

ADRAIN, J.M., WESTROP, S.R., CHATTERTON, D.E. and RAMSKÖLD, L., 2000. Silurian trilobite alpha diversity and the end-Ordovician mass extinction. Paleobiology, vol. 26, no. 4, pp. 625-646. http://dx.doi.org/10.1666/0094-8373(2000)026<0625:ST ADAT $>2.0 . \mathrm{CO} ; 2$.

AUMAN, H.J., MEATHREL, C.E. and RICHARDSON, A., 2008. Supersize me: does anthropogenic food change the body condition of silver gulls? A comparison between urbanized and remote, non-urbanized areas. Waterbirds, vol. 31, no. 1, pp. 122-126. http://dx.doi.org/10.1675/1524-4695(2008)31[122:SM DAFC]2.0.CO;2.

AYRES, M., AYRES JUNIOR, M., AYRES, D.L. and SANTOS, A.S., 2007. BioEstat 5.0: aplicações estatísticas nas áreas das ciências biológicas e médicas. Belém: MCT/CNPq. 364 p.
BARROS, F.B., PEREIRA, H.M. and VICENTE, L., 2011. Use and knowledge of the razor-billed curassow Pauxi tuberosa (spix, 1825) (galliformes, cracidae) by a riverine community of the Oriental Amazonia, Brazil. Journal of Ethnobiology and Ethnomedicine, vol. 7, no. 1, pp. 1-11. http://dx.doi.org/10.1186/1746-4269-7-1. PMid:21194497.

BERTSCH, C. and BARRETO, G.R., 2008. Abundancia y área de acción del paují de copete (Crax daubentoni) en los llanos centrales de Venezuela. Ornitologia Neotropical, vol. 19, pp. 287-293.

BIEBER, A.G.D., SILVA, P.S.D. and OLIVEIRA, P.S., 2013. Attractiveness of fallen fleshy fruits to ants depends on previous handling by frugivores. Ecoscience, vol. 20, no. 1, pp. 85-89. http://dx.doi.org/10.2980/20-1-3573

BIRDLIFE, 2014 [viewed 05 March 2014]. Species search [online]. Available from: http://www.birdlife.org/datazone/species/search\#.

BROOKS, D.M., 2006. Conserving cracids: the most threatened family of birds in the Americas. Houston: Houston Museum of Natural Science. 169 p. Miscellaneous Publications of the Houston Museum of Natural Science, no. 6

CAZETTA, E., ZUMSTEIN, L.S., MELO JÚNIOR, T.A. and GALETTI, M., 2008. Frugivory on Margaritaria nobilis L.f. (Euphorbiaceae): poor investment and mimetism. Revista Brasileira de Botanica $=$ Brazilian Journal of Botany, vol. 31, no. 2, pp. 303-308. http://dx.doi.org/10.1590/S0100-84042008000200012.

CHAPMAN, C.A. and CHAPMAN, L.J., 1995. Survival without dispersers: seedling recruitment under parents. Conservation Biology, vol. 9, no. 3, pp. 675-678. http://dx.doi.org/10.1046/j.15231739.1995.09030675.x.

DE CONTI, M.C.M.D., KITZBERGER, C.S.G., SCHOLZ, M.B.S. and PRUDENCIO, S.H., 2013. Características físicas e químicas de cafés torrados e moídos exóticos e convencionais. Boletim Centro de Pesquisa de Processamento de Alimentos, vol. 31, no. 1, pp. 161-172.

EISENBERG, J.F., 1980. The density and biomass of tropical mammals. In: M.E. SOULE and A.B. WILCOX, eds. Conservation biology: an evolutionary-ecological perspective. Massachusetts: Sinauer Associates, pp. 35-55.

FADINI, R.F. and MARCO JUNIOR, P., 2004. Interações entre aves frugívoras e plantas em um fragmento de mata atlântica de Minas Gerais. Ararajuba, vol. 12, no. 2, pp. 97-103.

FLEMING, T.H., 1992. How do fruit and nectar-feeding birds and mammals track their food resources? In: M.D. HUNTER, T. OHGUSHI and P.W. PRICE, eds. Effects of resource distribution on animal-plant interactions. San Diego: Academic Press, pp. 355-391.

FLEURY, M. and GALETTI, M., 2004. Effects of microhabitat on palm seed predation in two forest fragments in southeast Brazil. Acta Oecologica, vol. 26, no. 3, pp. 179-184. http://dx.doi. org/10.1016/j.actao.2004.04.003

FRANCISCO, M.R., LUNARDI, V.O. and GALETTI, M., 2007. Bird attributes, plant characteristics, and seed dispersal of Pera glabrata (Schott, 1858), (Euphorbiaceae) in a disturbed cerrado area. Brazilian Journal of Biology $=$ Revista Brasileira de Biologia, vol. 67, no. 4, pp. 627-634. http://dx.doi.org/10.1590/ S1519-69842007000400006. PMid:18278313.

FRISCH, J.D. and FRISCH, C.D., 2005. Aves brasileiras e plantas que as atraem. 3rd ed. São Paulo: Dalgas Ecoltec. 480 p. 
GALETTI, M., 1993. Diet of the scaly-headed parrot (Pionus maximiliani) in a semideciduous forest in southeastern Brazil. Biotropica, vol. 25, no. 4, pp. 419-425. http://dx.doi. org/10.2307/2388865.

GALETTI, M., GUEVARA, R., CÔRTES, M.C., FADINI, R., VON MATTER, S., LEITE, A.B., LABECCA, F., RIBEIRO, T., CARVALHO, C.S., COLLEVATTI, R.G., PIRES, M.M., GUIMARÃES JUNIOR, P.R., BRANCALION, P.H., RIBEIRO, M.C. and JORDANO, P., 2013. Functional extinction of birds drives rapid evolutionary changes in seed size. Science, vol. 340, no. 6136, pp. 1086-1090. http://dx.doi.org/10.1126/science.1233774. PMid:23723235.

GALETTI, M., MARTUSCELLI, P., OLMOS, F. and ALEIXO, A., 1997. Ecology and conservation of the Jacutinga Pipile jacuting $a$ in the Atlantic forest of Brazil. Biological Conservation, vol. 82, no. 1, pp. 31-39. http://dx.doi.org/10.1016/S0006-3207(97)00004-9.

GARCÍA-MORENO, J., CLAY, R.P. and RÍOS-MUÑOZ, C.A., 2007. The importance of birds for conservation in the Neotropical region. Journal für Ornithologie, vol. 148, no. 2, pp. 321-326. http://dx.doi.org/10.1007/s10336-007-0194-5.

GODOY, J.A. and JORDANO, P., 2001. Seed dispersal by animals: exact identification of source trees with endocarp DNA microsatellites. Molecular Ecology, vol. 10, no. 9, pp. 2275-2283. http://dx.doi.org/10.1046/j.0962-1083.2001.01342.x. PMid:11555269.

GRANT, P.R. and GRANT, B.R., 2006. Evolution of character displacement in Darwin's finches. Science, vol. 313, no. 5784, pp. 224-226. http://dx.doi.org/10.1126/science.1128374. PMid:16840700.

GUIX, J.C. and RUIZ, X., 1997. Weevil larvae dispersal by guans in southeastern Brazil. Biotropica, vol. 29, no. 4, pp. 522-525. http://dx.doi.org/10.1111/j.1744-7429.1997.tb00047.x.

GUIX, J.C., 2006. Complex plant-disperser-pest interactions in NW Amazonia: beetle larvae and companions travelling inside Attalea maripa palm nuts. Orsis, vol. 21, pp. 83-90.

GUIX, J.C., RUIZ, X. and JOVER, L., 2001. Resource partitioning and interspecific competition among coexisting species of guans and toucans in SE Brazil. Netherlands Journal of Zoology, vol. 51, no. 3, pp. 285-297. http://dx.doi.org/10.1163/156854201753247550.

HAMMER, O., HARPER, D.A.T. and RYAN, P.D., 2001 [viewed 22 December 2013]. PAST: Paleontological Statistics software package for education and data analysis. Palaeontologia Electronica [online], vol. 4, pp. 1-9. Available from: http://palaeo-electronica. org/2001_1/past/issue1_01.htm.

HARPER, K.A., MACDONALD, S.E., BURTON, P.J., CHEN, J., BROSOFSKE, K.D., SAUNDERS, S.C., EUSKIRCHEN, E.S., ROBERTS, D., JAITEH, M.S. and ESSEEN, P., 2005. Edge influence on forest structure and composition in fragmented landscapes. Conservation Biology, vol. 19, no. 3, pp. 768-782. http://dx.doi.org/10.1111/j.1523-1739.2005.00045.x.

HOWE, H.F. and ESTABROOK, G.F., 1977. On intraspecific competition for avian dispersers in tropical trees. American Naturalist, vol. 111, no. 981, pp. 817-832. http://dx.doi.org/10.1086/283216.

HOWE, H.F., 1984. Implications of seed dispersal by animals for tropical reserve management. Biological Conservation, vol. 30, no. 3, pp. 261-281. http://dx.doi.org/10.1016/0006-3207(84)90087-9.

HOWE, H.F., SCHUPP, E.W. and WESTLEY, L.C., 1985. Early consequences of seed dispersal for a neotropical tree (Virola surinamensis). Ecology, vol. 66, no. 3, pp. 781-791. http://dx.doi. org/10.2307/1940539.
JANZEN, D.H., 1970. Herbivores and the number of tree species in tropical forests. American Naturalist, vol. 104, no. 940, pp. 501-528. http://dx.doi.org/10.1086/282687.

JORDANO, P., GALETTI, M., PIZO, M.A. and SILVA, W.R., 2006. Ligando frugivoria e dispersão de sementes à biologia da conservação. In: C.F.D. ROCHA, H.G. BERGALLO, M.V. SLUYS and M.A.S. ALVES, eds. Biologia da conservação: essências. São Carlos: Editora Rima, pp. 411-436.

KATTAN, G.H., RONCANCIO, N., BANGUERA, Y., KESSLERRIOS, M., LONDOÑO, G.A., MARÍN, O.H. and MUÑOZ, M.C., 2014. Spatial variation in population density of an endemic and endangered bird, the Cauca Guan (Penelope perspicax). Tropical Conservation Science, vol. 7, no. 1, pp. 161-170.

KINNAIRD, M.F., O'BRIEN, T.G. and SURYARDI, S., 1996. Population fluctuation in sulawesi red-knobbed hornbills: tracking figs in space and time. The Auk, vol. 113, no. 2, pp. 431-440. http://dx.doi.org/10.2307/4088909.

LAURANCE, W.F., LOVEJOY, T.E., VASCONCELOS, H.L., BRUNA, E.M., DIDHAM, R.K., STOUFFER, P.C., GASCON, C., BIERREGAARD, R.O., LAURANCE, S.G. and SAMPAIO, E., 2002. Ecosystem decay of Amazonian forest fragments: a 22-year investigation. Conservation Biology, vol. 16, no. 3, pp. 605-618. http://dx.doi.org/10.1046/j.1523-1739.2002.01025.x.

LEITÃO FILHO, H.F., 1992. A flora arbórea da Serra do Japi. In: L.P.C. MORELLATO, ed. História natural da Serra do Japi: ecologia e preservação de uma área florestal no sudeste do Brasil. Campinas: Editora da Unicamp, pp. 40-62.

LOISELLE, B.A. and BLAKE, J.G., 2002. Potential consequences of extinction of frugivorous birds for shrubs of tropical wet forest. In: D.J. LEVEY, W.R. SILVA and M. GALETTI, eds. Seed dispersal and frugivory: ecology, evolution and conservation. New York: CABI Publishing, pp. 397-406.

LOPES, M.A. and FERRARI, S.F., 2000. Effects of human colonization on the abundance and diversity of mammals in eastern Brazilian Amazonia. Conservation Biology, vol. 14, no. 6, pp. 1658-1665. http://dx.doi.org/10.1046/j.1523-1739.2000.98402.x.

LORENZI, H., 2008. Árvores brasileiras: manual de identificação e cultivo de plantas arbóreas nativas do Brasil. 5th ed. Nova Odessa: Plantarum Publisher. vol. 1, 384 p.

MACE, G.M., HARVEY, P.H. and CLUTTON-BROCK, T.H., 1983. Vertebrate home-range size and energetic requirements. In: I.R. SWINGLAND and P.J. GREENWOOD, eds. The ecology of animal movement. Oxford: Clarendon Press, pp. 32-53.

MCKEY, D., 1975. The ecology of coevolved seed dispersal systems. In: L.E. GILBERT and P.H. RAVEN, eds. Coevolution of animals and plants. Austin: University of Texas Press, pp. 159-191.

MELLO, M.A.R., KALKO, E.K.V. and SILVA, W.R., 2008. Movements of the bat Sturnira lilium and its role as a seed disperser of Solanaceae in the Brazilian Atlantic forest. Journal of Tropical Ecology, vol. 24, no. 2, pp. 225-228. http://dx.doi. org/10.1017/S026646740800480X.

MERLER, J.A., DIUK-WASSER, M. and QUINTANA, R.D., 2001. Winter diet of Dusky-legged Guan (Penelope obscura) at the Paraná River Delta region. Studies on Neotropical Fauna and Environment, vol. 36, no. 1, pp. 33-38. http://dx.doi.org/10.1076/ snfe.36.1.33.8886.

MIKICH, S.B., 2002. A dieta frugívora de Penelope superciliaris (Cracidade) em remanescentes de floresta estacional semidecidual 
no centro-oeste do Paraná, Brasil e sua relação com Euterpe edulis (Araraceae). Ararajuba, vol. 10, no. 2, pp. 207-217.

MORELLATO, L.P.C. and LEITÃO FILHO, H.F., 1992. Padrões de frutificação e dispersão na Serra do Japi. In: L.P.C. MORELLATO, ed. História natural da Serra do Japi: ecologia e preservação de uma área florestal no sudeste do Brasil. Campinas: Editora da Unicamp, pp. 112-140.

MULLER-LANDAU, H.C. and HARDESTY, B.D., 2005. Seed dispersal of woody plants in tropical forests: concepts, examples and future directions. In: D.F.R.P. BURSLEM, M.A. PINARD and S.E. HARTLEY, eds. Biotic Interactions in the Tropics: their role in the maintenance of species diversity. Cambridge: Cambridge University Press, pp. 267-309.

MUÑOZ, M.C. and KATTAN, G.H., 2007. Diets of cracids: how much do we know? Ornitologia Neotropical, vol. 18, no. 1, pp. 21-36.

OTTONI, I., OLIVEIRA, F.F.R. and YOUNG, R.J., 2009. Estimating the diet of urban birds: The problems of anthropogenic food and food digestibility. Applied Animal Behaviour Science, vol. 117, no. 1-2, pp. 42-46. http://dx.doi.org/10.1016/j.applanim.2008.11.002.

PARRA, J.L., AGUDELO, M., MOLINA, Y. and LONDOÑO, G., 2001. Use of space by a pair of salvin's curassows (Mitu salvini) in northwestern Colombian Amazon. Ornitologia Neotropical, vol. 12 , no. 3 , pp. 189-204.

PASCOTTO, M.C., 2007. Rapanea ferruginea (Ruiz \& Pav.) Mez. (Myrsinacea) como uma importante fonte alimentar para as aves em uma mata de galeria no interior do Estado de São Paulo. Revista Brasileira de Zoologia, vol. 24, no. 3, pp. 735-741. http:// dx.doi.org/10.1590/S0101-81752007000300026.

PEEL, M.C., FINLAYSON, B.L. and MCMAHON, T.A., 2007. Update world map of the Köppen-Geiger climate classification. Hydrology and Earth System Sciences, vol. 11, no. 5, pp. 16331644. http://dx.doi.org/10.5194/hess-11-1633-2007.

PERES, C.A., 2000. Effects of subsistence hunting on vertebrate community structure in Amazonian forests. Conservation Biology, vol. 14 , no. 1 , pp. $240-253$. http://dx.doi.org/10.1046/j.15231739.2000.98485.x.

PIEROTTI, R. and ANNETT, C.A., 1991. Diet choice in the Herring Gull constraints imposed by reproductive and ecological factors. Ecology, vol. 72, no. 1, pp. 319-328. http://dx.doi. org/10.2307/1938925

PINTO, H.S., 1992. Clima na Serra do Japi. In: L.P.C. MORELLATO, ed. História natural da Serra do Japi: ecologia e preservação de uma área florestal no sudeste do Brasil. Campinas: Editora da Unicamp, pp. 30-38.

PIZO, M.A., 2004. Frugivory and habitat use by fruit-eating birds in a fragmented landscape of southeast Brazil. Ornitologia Neotropical, vol. 15, pp. 117-126.

POWELL, G.V. and BJORK, R.D., 2004. Habitat linkages and the conservation of tropical biodiversity as indicated by seasonal migrations of three-wattled Bellbirds. Conservation Biology, vol. 18 , no. 2 , pp. 500-509. http://dx.doi.org/10.1111/j.15231739.2004.00044.x.

R DEVELOPMENT CORE TEAM, 2008 [viewed 22 December 2013]. R: a language and environment for statistical computing [online]. Vienna: R Foundation for Statistical Computing. Available from: http://www.r-project.org/.
ROCHELLE, A.L.C., CIELO FILHO, R. and MARTINS, F.R., 2011. Florística e estrutura de um trecho de Floresta Ombrófila Densa Atlântica Submontana no Parque Estadual da Serra do Mar, em Ubatuba/SP, Brasil. Biota Neotropica, vol. 11, no. 2, pp. 337-346. http://dx.doi.org/10.1590/S1676-06032011000200032.

RUXTON, G.D., 2006. The unequal variance t-test is an underused alternative to Student's t-test and the Mann-Whitney U test. Behavioral Ecology, vol. 17, no. 4, pp. 688-690. http://dx.doi. org/10.1093/beheco/ark016.

SANTAMARÍA, M. and FRANCO, A.M., 2000. Frugivory of salvin's curassow in a rainforest of the Colombian Amazon. The Wilson Bulletin, vol. 112, no. 4, pp. 473-481. http://dx.doi. org/10.1676/0043-5643(2000)112[0473:FOSSCI]2.0.CO;2.

SARACCO, J.F., COLLAZO, J.A., GROOM, M.J. and CARLO, T.A., 2005. Crop size and fruit neighborhood effects on bird visitation to fruiting Schefflera morototoni trees in Puerto Rico. Biotropica, vol. 37, no. 1, pp. 81-87. http://dx.doi.org/10.1111/ j.1744-7429.2005.04040.x.

SCHAEFER, H.M., SCHMIDT, V. and BAIRLEIN, F., 2003. Discrimination abilities for nutrients: Which difference matters for choosy birds and why? Animal Behaviour, vol. 65, no. 3, pp. 531-541. http://dx.doi.org/10.1006/anbe.2003.2089.

SCHMIDT, V., SCHAEFER, H.M. and WINKLER, H., 2004. Conspicuousness, not colour as foraging cue in plant-animal signalling. Oikos, vol. 106, no. 3, pp. 551-557. http://dx.doi. org/10.1111/j.0030-1299.2004.12769.x.

SERIO-SILVA, J.C. and RICO-GRAY, V., 2002. Interacting effects of forest fragmentation and howler monkey foraging on germination and dispersal of fig trees. Oryx, vol. 36, no. 3, pp. 266-271. http://dx.doi.org/10.1017/S0030605302000480.

SERRA DO JAPI, 2015 [viewed 07 October 2015]. Serra do Japi: clima [online]. Jundiaí: Non-governmental organization Friends of the neighborhoods. Available from: http://www.dedoverde. com.br/japi/wp/?page_id $=126$.

SICK, H., 1997. Ornitologia brasileira. 3rd impr. Rio de Janeiro: Editora Nova Fronteira. 912 p.

SILVA, J.M.C. and TABARELLI, M., 2000. Tree species impoverishment and the future flora of the Atlantic Forest of northeast Brazil. Nature, vol. 404, no. 6773, pp. 72-74. http:// dx.doi.org/10.1038/35003563. PMid:10716443.

SILVA, W.R., 1992. As aves da Serra do Japi. In: L.P.C. MORELLATO, ed. História natural da Serra do Japi: ecologia e preservação de uma área florestal no sudeste do Brasil. Campinas: Editora Unicamp, pp. 238-263.

STAGGEMEIER, V.G. and GALETTI, M., 2007. Impacto humano afeta negativamente a dispersão de sementes de frutos ornitocóricos: uma perspectiva global. Revista Brasileira de Ornitologia, vol. 15, no. 2, pp. 281-287.

STEPHENS, D., BROWN, J.S.W. and YDENBERG, R.C., 2007. Foraging: behavior and ecology. Chicago: The University of Chicago Press. 608 p.

TABARELLI, M. and MANTOVANI, W., 1999. A riqueza de espécies arbóreas na floresta atlântica de encosta no estado de São Paulo (Brasil). Revista Brasileira de Botanica $=$ Brazilian Journal of Botany, vol. 22, no. 2, pp. 217-223. http://dx.doi. org/10.1590/S0100-84041999000200012.

THÉRY, M., ÉRARD, C. and SABATIER, D., 1992. Les fruits dans le régime alimentaire de Penelope marail (Aves, Cracidae) en 
forêt guyanaise: frugivorie stricte et sélective? Revue d Ecologiela Terre et La Vie, vol. 47, no. 4, pp. 383-401.

TSAHAR, E., FRIEDMAN, J. and IZHAKI, I., 2002. Impact on fruit removal and seed predation of a secondary metabolite, emodin, in Rhamnus alaternus fruit pulp. Oikos, vol. 99, no. 2, pp. 290-299. http://dx.doi.org/10.1034/j.1600-0706.2002.990209.x.

WHEELWRIGHT, N.T., 1985. Fruit size, gape width, and the diets of fruit-eating birds. Ecology, vol. 66, no. 3, pp. 808-818. http://dx.doi.org/10.2307/1940542.
YUMOTO, T., 1999. Seed dispersal by Salvin's Curassow, Mitu salvini (Cracidae), in a tropical forest of Colombia: Direct measurements of dispersal distance. Biotropica, vol. 31, no. 4, pp. 654-660. http://dx.doi.org/10.1111/j.1744-7429.1999. tb00414.x.

ZACA, W., SILVA, W.R. and PEDRONI, F., 2006. Diet of the rusty-margined guan (Penelope superciliaris) in an altitudinal forest fragment of southeastern Brazil. Ornitologia Neotropical, vol. 17 , pp. 373-382. 